\title{
Animate, Inanimate and Beyond in Švankmajer's Faust (1994)
}

Laura Pontieri

Jan Švankmajer's films are not meant to be simply watched but they are created to be intensely experienced - they inescapably provide a powerful feeling of disorientation. Not only are reality, performance, memory and fantasy intersected, but the inhabitants of these "realities" switch from human beings, to objects, puppets, and fantastic figures made by a mixture of all the above. The space in which these characters move is a transitional space, a meeting point of oneiric reality, natural reality, and fictional reality, in which theatricality is often underlined.

In this contribution, I would like to suggest that a semiotic approach along the line of the heritage of the Prague school could help to understand the audience's peculiar reactions to Švankmajer's continuous crossing of boundaries. Once we approach Švankmajer's works from a semiotic point of view, we realize how freely he switches from one set of signs to another, dwelling specifically on the space between these systems, exploring, as a faithful surrealist, "the conjunctions, the points of contact, between different realms of existence" (RICHARDSON 2006: 3). The effect is one of bewilderment and unsettlement that ranges from comic to dread.

In order to investigate how Švankmajer provokes these various reactions from his spectators, I would like to borrow some insights from the scholars of the Prague school about the distinctive quality of the sets of signs that shape each kind of performing art and provide as an example Švankmajer's film Faust (Lekce Faust, 1994).

\section{Blurred lines among pictorial, theatre, puppet theater and filmic systems of signs}

In his article "A Contribution to the Study of Theatrical Signs," Bogatyrev insists on defending the unique quality of a system of signs that forms the work of art in question, 
which might be different from a set of signs that shapes another kind of similar artistic expression; in particular, he claims that we should watch puppet theatre with an understanding of the signs that form this unique performing art, avoiding an interpretation based on signs from other arts, such as for example the signs of live-action theatre (BOGATYREV 2016 [1937/8]: 93).

Failing to make this distinction between sets of signs of different performing arts, Bogatyrev continues, would affect the spectator's perception of the performance (BOGATYREV 2016 [1937/8]: 95-96). This is particularly interesting in Švankmajer's works, in which conventions of live-action film, theatre, puppet theatre, and animation continuously cross and clash.

In Švankmajer's feature films these systems are not clearly defined and separated from each other. Švankmajer uses live-action and animation interchangeably, intermingling them with the filming of theatrical performances. There is a fine line that distinguishes these performances, and often the disruption of this line becomes the source of bafflement and disorientation. Indeed, Švankmajer's surrealist focus on the border of realities deliberately startles the spectator and aims to suggest a new dimension of the everyday contact with reality.

Everyone and everything in Švankmajer's films is misplaced and presented in a way that seems to follow Shklovsky's ostranenie - the desire to turn the familiar into something that acquires a new meaning and function. But at Švankmajer's hands, this feeling of de-familiarization reaches the point of subversion. A study of Švankmajer's use of various conventions, namely pictorial, filmic, puppet and theatrical in his film Faust will provide some concrete examples of the director's approach to fiction and reality.

The very beginning of the film brings us to the pictorial world, almost an epigraph to the entire film. Etchings of grotesque devils and alchemist tools are presented on the screen, providing the mood for the film and, in a way, anticipating the theme. The etchings are juxtaposed with shots of a Prague subway escalator that brings to the surface, as though coming from hell, common people. Among the figures emerging onto the surface, is an ordinary man whom the camera tracks and zooms in. The movement of the camera is the only device that distinguishes this man from the rest of the crowd. The man - played by the actor Petr Čepek - has nothing that draws one's attention, he is wearing plain clothes and maintains a neutral facial expression. As many others around him, at the crossroad, he receives a leaflet with a map inscribed on it. Like many others, he discards it, but neither he nor the audience know yet that all attempts to get rid of this leaflet are futile. From the moment he arrives at home, the character seems to lose control not only of what surrounds him, but also of his reactions to what happens around him - he does not appear to be particularly puzzled by his apartment being invaded by a black hen, his bread containing an egg, or the strange behaviour of the same men who handed him the leaflet now hovering under his window. After a few more eerily failed efforts to dispose of the leaflet, he decides to follow the map sketched on it. Soon the filmic reality transforms into theatrical reality. Once he arrives at the place marked on the map, he finds himself in a decapitated building through which he uncannily reaches a theatre backstage. Here, inexplicable forces bring him to 
take on the role of Faust. Costume, make-up, stage, and audience underline this shift from filmic to theatrical reality. An ominous red light - with some hell-like connotations - calls him to the stage. But once he is on stage, after peeking through the proscenium curtains and seeing the audience, he suddenly steps back. Here it seems that the only way of rebelling against this theatrical reality is getting rid of everything that constitutes a sign of it. Hence, he takes off his make-up, he divests himself of the Faust costume and literally breaks away from this enclosed system by cutting open the backdrop to escape resolutely the role of Faust. He flees the theatre, only to find himself in an alchemist room, where he assumes again the personification of Faust, the alchemist, the challenger of God. Here, by creating a Golem-like creature out of clay, he determines his unavoidable Faust-like fate. The theatre he escaped literally catches him up: a backdrop lowers from up top, wings from the side, and the first puppet - a warning messenger from heaven - makes its appearance.

In this scene, we recognize the signs that make up a theatre performance: the backdrop, the wings, and the source of artificial sounds, such as thunders created by shaking a metal flat board. More specifically we are in front of signs of the puppet theatre: the rigid wooden puppets, their strings moved by a puppeteer, their stiff and mechanical gestures. Once we recognize these signs, Bogatyrev notices, we accept the puppets for what they are and the performance on stage as "merely a theatrical embodiment of life and not life itself" (BOGATYREV 2016 [1937/8]: 91).

We almost forget that the stage appears from nowhere, and these puppets' heads come from a reality outside the theatre, moved by an invisible force. The actor takes a seat and glimpses up towards the puppeteer's hands, as though he accepts in the most natural way his position as a spectator of this performance. But suddenly we are unexpectedly taken aback when one puppet directly addresses our main character (hence, breaking the invisible fourth wall that divides the performance from the spectator) and invites him to meet Cornelius and Valdes. This invite transforms our character from a passive spectator into an active agent again and has a twofold effect. On the one hand, it places again the main character in a theatrical realm - these two personages, or at least their names, come from Marlowe's tragedy. ${ }^{1}$ But at the same time, it brings the character to leave the system of theatrical signs and enter the set of filmic signs - the character, in fact, will meet the two "friends" outside of the theatre, in a tavern. This switch of place is accompanied by specific contemporary references that concretize the Czech location and identify Cornelius and Valdes as ordinary swindlers: the two figures are eating traditional Czech food, the waiter customarily marks a line on a piece of paper for each beer ordered, they pass a bag under the table without exchanging a world - maybe a reference to illegal activities in the post-Soviet era as noted by Drábek and North (2011: 528) - and then they leave without paying. The

1 The earliest printed collection of Faust stories is considered to be the German Historia von D. Johann Fausten known also as the Faustbuch (published by Johann Spies in 1587), which was translated in many languages. Christopher Marlowe probably based his The Tragical History of Doctor Faustus (1604) on the English translation. The myth of Faust, however, does not solely originate from literary versions, but largely from many popular legends of the 16th century, folk tales, and German and Czech puppet theatre. 
scene brings us to our everyday reality and its filmic rendition and, in doing so, is the viewer's first invitation to recognize Faust's status in each one of us.

\section{Dialogues or monologues? Script and dramatic text}

The entire scene takes place with no words, only gestures. Švankmajer's approach to script, dramatic text and mimicry denotes one more aspect of his film as a hybrid of performances. Throughout the film, dialogues derive exclusively from dramatic texts meant for theatrical performances, namely Christopher Marlowe's Doctor Faustus (1604), Johann Wolfgang von Goethe's Faust (1808-1832), Christian Dietrich Grabbe's play Don Juan and Faust (1828), Charles Gounod's opera Faust (premiered in 1859) and the many variants of the marionette play. The filmic actor speaks solely with words drawn from these works. What belongs to the system of signs of the theatre is here adopted in the film. This complete avoidance of an independent film script creates, at first, a sense of disorientation in the spectator. But soon, quite eerily, the spectator begins to accept the artificial dialogue as a natural part of the product that is Švankmajer's film, a peculiar performance composed by a system of constantly mutable signs.

The dramatic dialogue in Švankmajer's hands is not only literally adopted in the film but it is also the prey of further "mutations" (as is everything and everyone in Švankmajer's films). The first step towards a dismantling of the dramatic dialogue is the passage from dialogue to monologue. Indeed, the actor's utterances feel rather more like monologues than part of a dialogue. Švankmajer not only plays with the intrinsic "dialogic nature of mental activity" (MUKǍ̌RVSKÝ 1940: 236), but he goes beyond it.

In an attempt to point out the differences between dialogue and monologue, Veltruský and Mukařovský define dialogue as a specific kind of semantic construction, in which two or more contexts interpenetrate and alternate, whereas a property of monologue is a single and continuous context which expresses the speaker's attitude toward the theme (VELTRUSKÝ 1976a: 129; MUKAŘOVSKÝ 2016a [1940]: 225). In dramatic dialogue, Veltruský continues, the semantic construction is even more complicated, since "dramatic dialogue is both a sequence of alternating utterances made by several speakers and an utterance made by a single speaker, the author" (VELTRUSKÝ 1976a: 130). Mukařovský, in addition, identifies another participant, the spectator, "silent but important, for everything that is said in a dramatic dialogue is oriented toward him, toward affecting his consciousness" (MUKAǨOVSKÝ 2016b [1941]: 213). In Švankmajer's film, the original authors' dramatic dialogues are extrapolated from the framework of the actual plays and passively adopted by the filmic actor. Švankmajer's use of different texts from different authors creates a shift from a dramatic dialogue formed by several speakers' lines - including the author's voice - to a monologue (despite the various voices that materialize the utterances), in which the original authors' utterance is re-appropriated by the film director and affectively directed towards the audience's consciousness. According to Veltruský, dialogue unfolds in a specific "here and now," while monologue unfolds only in time (VELTRUSKÝ 1976a: 128). The dialogues 
we hear in the film do not seem to take place "here," they are echoes of words written for someone else, pronounced at other times in other theatrical words. The space component is lost, the dialogues transform into monologues, the words pronounced acquire another dimension.

This approach creates an unsettling situation. On the one hand, the filmic system of signs is disrupted by the adoption of dramatic dialogues transposed in a filmic setting with no intention of fully adopting all the conventions of theatre (which would make the film a filmic rendition of a theatrical performance). On the other hand, the dramatic dialogue loses its intrinsic qualities, and not only does it turn into monologue but also into something that goes beyond the utterance of words. Švankmajer tries to distill from the dialogues the quintessence of the various original authors' thoughts, but then, he uses them for his own purpose, creating a version of Faust who lacks his traditional thirst for knowledge, is passive from the very beginning, and utters words without fully believing in them, as though they were detached from himself. This makes of Faust a puppet, an empty shell animated by an external force, whose words do not come from within but through it. This tension created by the manipulation of the utterances provokes a sense of bafflement and instability in the audience.

\section{Mephistopheles - interlocutor, Faust's double or dreadful automaton?}

The transformation of dialogues into monologue is emphasized by the silence of all other characters and the specific role of Mephistopheles, Faust's only interlocutor. Most of the time, the devil servant serves the mere task to prompt Faust to continue reciting his lines, he embodies, as also intrinsically in the literary Faust, the splitting of Faust's consciousness. In this film, the division of his consciousness into two subjects takes a concrete form: Mephistopheles' face morphs not only into a mobile clay mask but, most importantly, into a clone of the actor, a double. The continued metamorphoses emphasize the disruption of the line that distinguishes Faust and the devil, external and internal discourses, reality and supernatural.

A strong effect is achieved also by the emphasis placed on Mephisotphele's facial movements. According to Veltruský, "the movement of facial muscles is one of a person's most effective resources in expressing his personality and state of mind" (VELTRUSKÝ 1976b: 258). Here, the movements of the muscles in Mephistopheles's clay face are overemphasized, achieving, paradoxically, an effect of neutralization of the semiotic qualities of the face similar to what is achieved by an immobile mask used in some forms of theatre (VELTRUSKÝ 1976b: 258). In the mask tradition of the Greek tragedy, as Veltruský's notices, "it was the dramatist's word rather than the play of facial muscles that gave the face its specific meanings" (VELTRUSKY 1976b: 259). In the hands of Švankmajer, Mephistopheles's clay face is mobile (as everything in Švankmajer's works seems to move and have a life of their own), but its exaggerated movements together with an inflectionless and flat intonation make of it an automaton. Mephistopheles, thus, is deprived of its independent personality, he too is presented as a mere shell 
through which Faust's thoughts would come out, but once again, these words come as detached from both Faust or Mephistopheles, as though coming from universal truths. It is not relevant who is saying the words, they belong to the same realm, they are expressions of the same monologue. The emphasis is on how the words are pronounced and the following effect. Švankmajer achieves in this instance almost the effect of foregrounding (aktualizace) as described by the Prague School in poetic language, whereas "[foregrounding] is not used in the services of communication, but in order to place in the foreground the act of expression, the act of speech itself” (MUKǍ̌OVSKÝ 1983: 169). Švankmajer once more appropriates an important dramaturgic element of the theatrical system and turns it upside down. Mephistopheles' monotone inflections subverts the "usual" actors' attempt to give life to their words and results in a more powerful and dreadful effect.

\section{Disrupted unity of time and space}

Švankmajer's re-appropriation and re-creation of performing art conventions manifest not only in the manipulation of text and utterances but also in the violation of unity of time and space. The scene in the taverna mentioned above brings us back to our recognizable reality for just a moment before shattering every conceivable notion of reality and continuity of space. While Faust recites the magic formulas to summon the devil, space fills with animated sweeping brooms followed by swift changes of settings, from a location on the top of a tall tower to snow-like white desert, from rocks and boulders to forest. A continuous flow of different locations portrays an illogical reality and, thus, undermines the traditional conventions of the unity of space in the film. Whereas film space is usually provided by a progression of a sequence of pictures, each of them "accompanied by an awareness of the unity of the total space" (MUKAǨOVSKÝ 1977: 184); in Švankmajer each successive picture defeats our attempts to create a total space that would make sense. Space transforms continuously from one scene to another in an irrational way, in the same way as we experience dreams. The Bakhtinian chronotope shatters, there is no more "connectedness of temporal and spatial relationships” (BAKHTIN 1981: 85). The continuity of speech contrasts with the violation of the unity of space; the character travels while being static. The time of the utterance prevails over space only to create another dimension, in which the Latin formulas originate a timeless scene - the ancient words bring us back to different times and places in which the same words might have been uttered. At the same time, space turns into a dimension in between the physical reality we are accustomed to and a supernatural existence. There is no more a concrete chronotope, Švankmajer seems to create his own idea of space and time that fits his surrealist view of reality. 


\section{Puppets as actors in a surrealist, grotesque, and fantastic world}

The clash between the supernatural scenes that appear on the screen and the actor's attitude towards the event creates what Todorov defines as the "fantastic effect" (TODOROV 1973: 26). Spectators perceive the uncanny phenomena as created by supernatural causes, while the actor treats the events and changes of scene in the most natural way, he does not show any hesitation, any wonder. There is no audience's identification with the actor, only the eerie feeling of the fantastic.

The uncanny feeling that pervades the film is also linked with Švankmajer's fascination with the kind of grotesque world described by Kayser: a world that is - and, at the same time, is not - our own world, which is familiar and apparently harmonious until the impact of an alien, inhuman power breaks it up and crushes its coherence (KAYSER 1968: 37).

Inhabitants of this alienated world are Švankmajer's uncanny puppets. The director plays with our twofold perception of a puppet. On the one hand, we perceive puppets as elements of puppet theatre, which is defined by proper conventions such as characters with strings moved by a puppeteer, a stage, backdrop, wings and artificial source of the sound. Švankmajer's adoption of traditional wooden puppets reinforces this perception. However, his creation of human-size puppets, instead of the original smaller version, provokes a certain friction in the perception of folk figures. We indeed perceive his life-size puppets closer to human beings than the familiar wooden marionettes, especially once the puppets leave the theatre free from the tie of their strings and acquire a life of their own. Once the signs that distinguish the theatrical conventions are removed, the puppets attain human connotations. As Zich points out in his study on puppet theatre, our perception of the puppet is always ambiguous, in between the understanding of the puppet as an object and the acceptance of it as a living being:

The controversy [of puppet theatre] is thus in the realm of perception itself: according to the presence of movement and speech we have a live person before us; according to other [equally sensorial] signs, we have un-live matter, a puppet. [...] the controversy exists in the dual conception of what we perceive: puppets may be either taken for live people, or as unlive puppet. (ZICH 2015: 506)

Švankmajer indulges in this twofold perception, constantly surprising the spectator. He often places emphasis on the puppets' apparent manifestations of life, making us perceive them more as living beings than inanimate wooden objects. As Zich again notes:

In such a perceptive mode, the awareness of the factual un-liveness of puppets moves to the background and it is apparent merely as a sensation of something inexplicable, a certain mystery that raises a sense of amazement. In this case, puppets have an uncanny effect on us. If they had real human size and their facial expressions were as perfect as can be, the sensation created in such a conception could accordingly be one of terror. (ZICH 2015: 507) 
Švankmajer brings this perception to an extreme: his puppets do acquire a life of their own, and their size does emphasize the effect. Hence, we are taken aback when we see the human size puppet impersonating Faust's servant eating real food. In this scene a cinematic convention (the close-up) leads our eyes to details that underline the fictitious quality of the character - enlarged on the big screen we see a close-up of the puppet's wooden hand and face, its/his mouth stuffed up with food, and its jaw opening and closing in a frightful, mechanical way. The clashing of the systems of signs we are accustomed to provokes an overall dreadful effect. Bogatyrev notices that "the perception of the system of signs creating a work of art as a living person or a real thing" creates a sensation of uncanniness, but also the same feeling of uneasiness or even terror could be the result of a situation in which "a sign of some particular system is perceived as a sign of another system” (BOGATYREV 2016 [1937/8]: 94).

When we feel the tension in our perception of one system against the background of another, Bogatyrev insists on the necessity to focus on the signs intrinsic to the art we are perceiving, which needs to predominate. Švankmajer makes this task quite challenging. Reality - in the sense of filmic reality, a setting that it would seem naturally belonging to the signs of the live-action film - becomes theatre, then theatre becomes reality, and then again repetitively reality becomes a stage. Puppets appear on stage manipulated by a puppeteer, but then they acquire a life of their own, we see them even in the washroom as the ultimate sign of a human (and certainly not puppetlike) base need. This is clearly also a hint to the grotesque Bakhtinian material bodily principle, by which Švankmajer is so fascinated. Attention on material needs of the body, the Bakhtinian lower stratum, is evident in much of Švankmajer's works, namely in his dwelling on sexual instincts, as well as his obsession with the consummation of food and drinks, often materialized with his signature extreme-close-ups of mouths. Elements typical of the grotesque world as described by Bakhtin in his study of Rabelais, namely excessive consumption, birth, decomposition, and regeneration, are in Švankmajer's films real and tangible.

\section{Actors as puppets}

In the same way that puppets acquire a life of their own, Faust takes over the actor's life, bringing him into a reality outside of the stage. Interestingly this Faust does not rebel (apart from the first short-lived attempt at the beginning of the film as mentioned above). Faust is - in Švankmajer's words

a "chance" person who has let himself be manipulated into a tragic position (role) which he plays dutifully to the bitter end. What it is really is a paradox - man is manipulated into the tragic position of Faust (the rebel Faust) and does not even rebel against this manipulation. I believe this is a problem which is contemporary and topical. (ŠVANKMAJER 1998: 118) 
The reality of the theatre becomes the reality of the film, which in its turn, points to our contemporary reality and our constant experience with manipulation. The jarring jumps from one reality to another, one system of signs to another, are purposefully unsettling.

The disruption of our expectations and the hindrance to our attempts to make sense of what we see according to our accustomed system of signs come to a climax once the actor is encased in a wooden puppet shell and is manipulated by strings. In this shape, the actor takes part in the theatrical performance - but is it a theatrical performance?

This scene starts with Faust singing the opera in front of a clapping audience. But then, his performance suddenly ends when he sees Mephistopheles in the prompter's box. At that moment, the eerie silence that befalls the theatre (you can hear Faust's steps echoing) makes us switch our reading of the scene from a theatre performance to the ambiguous filmic reality that pervades this film. This shift is emphasized by the disappearance of the audience, by Faust taking off his make-up and part of the costume, and by the actor directly addressing the prompter (and so violating a convention of a theatre performance). Once the two come to an agreement about signing Lucifer's pact, the actor turns into a puppet, now completely under the manipulator's control.

This transformation is at first accepted as part of the theatrical conventions, the wooden marionette that encases him is almost like a costume placed on the actor, but we cannot forget that inside is a "real" human being that is the character and the film actor at the same time; and the blood coming from the cut in the arm makes sure that we don't forget the living quality of the puppet. We feel uneasy because the actor encased in the wooden marionette is a sign of a human being like us and we dread the possibility of being trapped and manipulated by the disembodied hands of an otherwise invisible puppeteer.

We also feel unsettled because we are not sure how to read the signs in front of us. The stage takes turns with a reality outside of the stage, marionettes are moved by strings but, at the same time, have real blood running in their veins; then, puppets lose their strings and the entire scene shifts from theatrical performance to an ambiguous scene in the open air, until we are back to the theatrical performance with the reappearance of the audience in the theatre. The scene constantly makes us switch from a system of signs proper to theatre to one proper to live-action film, and finally to one that would suitably define animation cinema. At the end of the performance, Faust breaks out of his wooden shell, but he is still manipulated by strings and his movements resemble the abrupt gestures of a marionette until he ends up hung on the wall on a marionette hook as a helpless dummy. This is the result of his pact with the devil. But then, we wonder again, is this pact just a performance?

As Veronika Ambros points out in her article on the interrelation of Prague's experimental stage and the Prague School theoretical analysis of modern theatre, the scholars of the Prague School repetitively talk about the potential interchangeability between man and object on stage and the relevance of masks and puppets in modern theatre (AMBROS 2008: 52-58). As Ambros aptly argues, puppet theatre is seen as based "on 
the oscillation between the static and the dynamic, between the inorganic material and its animated appearance, between the mechanic and the anthropomorphic performance, and between fine arts (sculpture, painting) and performing arts" (AMBROS 2008: 56). In Švankmajer's film the actor comes closer to a puppet even when he is not dressed in a wooden shell; in the pact scene mentioned above, his static and mechanic features underline the sculptural and painting-like quality of its performance, as though Švankmajer aims to make of him an archetype of the puppet-like condition of a human being.

Švankmajer does not want us to identify with the character but with the universal human condition of beings constantly manipulated. In the film, Švankmajer obtains the same effect of alienation and separation between the character and the stage figure that was typical of modern theatre. The stage figure - i.e. the actor who appears on stage that differs from "the dramatic character that exists not on the stage but in our consciousness" (ZICH in AMBROS 2008: 57) - becomes in Švankmajer's film only a shell through which the director's ideas are brought forward. With this distancing device, Švankmajer aims to expose his idea of life as controlled by inexplicable forces, at a crossroad of many different realities being oneiric, real, fantastic or supernatural. In the Švankmajerian world, the stage figure easily turns into a puppet, into a mask, and briefly into an actor again. The character's will of playing along in a puppet disguise makes us uncertain of the situation. Who is leading? The actor in the puppet, the puppeteer, an invisible puppeteer beyond the theatrical or filmic representation? Švankmajer doesn't give us a precise answer in the film, he focuses more on disrupting the separation between reality and non-reality, but he certainly believes that: "The puppet is what best represents the position of man in today's manipulated world. The hand of a puppeteer is always the hand of he who "leads", the hand of the Great Manipulator" (ŠVANKMAJER 1998: 87). And later in Švankmajer’s words again:

I am convinced that we are constantly manipulated - by the stars, by our genes, by our repressed desires, by society, its education, advertising, repression of all kinds. We have to rebel against this manipulation - by creation, magic, revolt. This rebellion is the road to freedom (ŠVANKMAJER 1998: 119)

This comment once more reiterates Švankmajer's invitation to recognize the puppet directly as a sign of ourselves in our reality; it also impels us to accept the puppet for what it is and not in relation to the theatre or film actor, against which the puppet is usually perceived.

\section{Puppets within puppets}

The fine line that distinguishes filmic actor, dramatic character and puppets are once more obliterated when the director presents a puppet within a puppet. Shortly after Faust literally embodies a wooden puppet, the devil puppet enters the wooden shell 
of a woman marionette in order to allure Faust. We, as spectators, perceive what is in front of us according to certain signs that we attribute at this point to the cinematic conventions: the theatre stage is gone, the strings disappeared, and Faust, now divested of his wooden shell, is attracted by this feminine marionette as though it were a beautiful woman in flesh and blood. The character is striving to make us believe that this woman puppet belongs to the same system of signs as he is. In part he succeeds, because we are less concerned about him chasing a wooden marionette than him being deceived by the devil. The complexity of this process of the sign of signs has the effect to underline the unnatural lust that moves Faust - the pleasure of the flesh here is turned towards a wooden creature (not flesh at all). Moreover, the shifting signs strongly destabilize our notion of reality and contests our normal perception of the acting agents in the film. Once more we feel uneasy and disoriented.

\section{Spectators' shifting reception}

One last instance in which Švankmajer plays with different systems of signs provides us with a vivid example of how our perception of what is in front of us changes according to our position in relation to one system or another. At a certain point of the film, the puppet in the role of Faust's servant keeps on summoning the devil on stage. Every time he summons him, the devil comes from the street, a wooden marionette, human size and dressed in human clothes. He/it quickly gets undressed and appears on the stage, acquiring strings and full puppet qualities.

Although we have again a situation at the border of different systems, in this scene the set of signs of the puppet theatre prevails. In this case, we do take puppets as puppets, with an emphasis on their materiality. When we focus on the physical puppets, Zich notes, "we cannot take equally seriously their speech and movements, in brief, their 'manifestation of life;' we thus find them comical or grotesque" (ZICH 2015: 506-507). The puppets' rigidity and clumsiness contribute to the comedy of impression (ZICH 2015: 507). Similarly, in this scene, the puppets' performance provokes our smile along with the smirk of the character who is witnessing it in the film. The focus is on the comedic quality of the performance: the servant is taking advantage of his power to summon and dismiss devils and the devil needs to rush several times on stage. The comic effect is enhanced by the servant being in fact the Czech traditional jester Kašpárek, a character and marionette easily recognizable by the Czech audience. In this setting, the devil puppet's going back and forth camouflaged as a human being, although uncanny, becomes part of the performance. Here a filmic technique, the closeup, serves to emphasize theatrical conventions. If at first a close-up of a metallic board shaken to create a thundering sound lays bare a theatrical device; then, the close-up of the devil's chattering mouth together with the amplification of the unnatural sounds that come out of it underlines the theatricality of the scene.

But when we relax and get comfortable with the performance we see, Švankmajer calls upon us to reassess our perception. We are comfortable now that we accept 
a system of signs that create a performance, but what if we saw a dreadful wooden puppet moving by itself on the street dressed as a human being? The director uses his film to provide an answer: he shows us a lady on the street bumping into the disguised marionette, her dreadful look is a certain sign of the perception of this marionette against the background of another system not belonging to puppet theatrical performance.

Švankmajer shows us characters on screen, counting on our expectation to see them as signs of real-life people, then he disrupts our expectations by transforming continuously and unexpectedly the filmic actors into theatre actors and then into puppets, and traditional puppets into autonomous living being. When we think we understand what the signs point to, Švankmajer is ready to disrupt our expectations yet again.

Švankmajer's films provoke an uncanny feeling that it is often closer to dread than laughter. I would suggest that the reason lays in the fact that Švankmajer constantly disrupts our reading of reality according to the systems of signs we are accustomed to. While subverting conventions of performing arts and so undermining our notion of fiction against reality, Švankmajer threatens our recognition of ourselves as human, rational being in control of our surroundings.

\section{Bibliography}

AMBROS, Veronika. 2008. Prague's experimental stage: laboratory of theatre and semiotics. Semiotica 168 (2008): 45-65.

BAKHTIN, Mikhail M. 1968. Rabelais and his world. Cambridge, Mass: M.I.T. Press, 1968.

BAKHTIN. Mikhail M. 1981. Forms of time and of the chronotope in the novel. Notes toward a historical poetics. In Michael Holquist (ed.). The dialogic imagination. Four essays. Trans. Caryl Emerson and Michael Holquist. Austin: University of Texas Press, 1981: 84-258.

BOGATYREV, Petr. 2016 [1937/8]. A contribution to the study of theatrical signs. On the perception of signs in puppet theatre, theatre with live actors and art in general. In David Drozd, Tomáš Kačer and Don Sparling (eds.). Theatre theory reader. Prague School writings. Prague: Karolinum Press, 2016: 91-98.

DRÁBEK, Pavel and Dan NORTH. 2011. "What governs life": Švankmajer's Faust in Prague. Shakespeare Bulletin 29 (2011): 4: 525-542.

DROZD, David, KAČER Tomáš and Don SPARLING (eds.). 2016. Theatre theory reader. Prague School writings. Prague: Karolinum Press, 2016: 220-246.

KAYSER, Wolfgang. 1968. The grotesque in art and literature. Gloucester, Mass: P. Smith, 1968.

MATEJKA, Ladislav and Irwin R. TITUNIK (eds.). 1976. Semiotics of art. Prague School contributions. Cambridge: The MIT Press, 1976.

MUKǍ̌OVSKÝ, Jan. 2016a [1940]. Dialogue and monologue. In David Drozd, Tomáš Kačer and Don Sparling (eds.). Theatre theory reader. Prague School writings. Prague: Karolinum Press, 2016: 220-246.

MUKAŘOVSKÝ, Jan. 2016b [1941]. On stage dialogue. In David Drozd, Tomáš Kačer and Don Sparling (eds.). Theatre theory reader. Prague School writings. Prague: Karolinum Press, 2016: 212-215. 
MUKAŘOVSKÝ, Jan. 1977. A note on the aesthetic of film. Structure, sign, and function. Selected essays. New Haven: Yale University Press, 1977: 178-190.

MUKAŘOVSKÝ, Jan. 1983. Standard language and poetic language. In Josef Vachek and Libuše Dušková (eds.). Praguiana: some basic and less known aspects of the Prague Linguistic School. Amsterdam/Philadelphia: John Benjamins Publishing Company, 1983.

RICHARDSON, Michael. 2006. Surrealism and cinema. Oxford/New York: Berg, 2006.

ŠVANKMAJER, Jan and Eva ŠVANKMAJEROVÁ. 1998. Evašvankmajerjan. Anima Animus Animation, Between Film and Free Expression. Prague: Arbor Vitea Slovart Publishing, 1998.

TODOROV, Tzvetan 1973. The fantastic. A structural approach to a literary genre. Trans. Richard Howard. Cleveland: Press of Case Western Reserve University, 1973.

VELTRUSKÝ, Jiří. 1976a. Basic features of dramatic dialogue. In Ladislav Matejka and Irwin R. Titunik (eds.). Semiotics of art. Prague School contributions. Cambridge: The MIT Press, 1976: 128-133.

VELTRUSKÝ, Jiří. 1976b. Dramatic text as a component of theatre. In Ladislav Matejka and Irwin R. Titunik (eds.). Semiotics of art. Prague School contributions. Cambridge: The MIT Press, 1976: 247-267.

ZICH, Otakar. 2015. Puppet theatre. Theatralia 18 (2015): 2: 505-513. 